\title{
The Use of Different Indicators to Evaluate Chernozems Fluvisols Physical Quality in the Odra River Valley: A Case Study
}

\author{
Lukasz Borek* \\ Faculty of Environmental Engineering and Land Surveying, \\ Department of Land Reclamation and Environmental Development, \\ University of Agriculture in Kraków, Kraków, Poland
}

Received: 13 July 2018

Accepted: 24 September 2018

\begin{abstract}
The physical quality of alluvial soils in the Odra River Valley was studied. The field study was carried out on arable land in Tworków, in the south of Poland, in four soil pits (5 layers each) from which samples for laboratory analysis were taken. The assessment of the soil physical quality $(S P Q)$ was determined for selected indicators, including: plant-available water $(P A W)$, soil bulk density $(B D)$, organic carbon content $\left(C_{\text {org }}\right)$, structural stability index $(S t I)$ and soil physical quality index $(S$ index). The examined soils are heterogeneous in terms of texture and characterized by their high sand and silt content affecting the selected quality parameters of soil. Mean value of $P A W$ content was "ideal" for maximal root growth. The effect of human and agricultural activities are seen in a mean value of $B D$, which show moderate signs of compaction, low $C_{\text {org }}$ content, and also according to StI very high risk of degradation. The use of $S$ index as an indicator of $S P Q$ is less reliable than other indicators, because it is calculated based on results from RETC simulation. On the other hand, the values of $S$ are significantly correlated with $P A W$ content, which were obtained from the laboratory measurements.
\end{abstract}

Keywords: floodplain soil; structural stability index; S index; plant-available water; bulk density

\section{Introduction}

Soil quality is a very important issue that continuously evaluates and develops in different countries. The concept of soil quality was developed in the $20^{\text {th }}$ century and contains three main aspects: physical, chemical and biological [1-3]. From an agricultural point of view, soil physical quality $(S P Q)$

*e-mail:1.borek@ur.krakow.pl decreases mainly in cases of soil cultivation due to decreases in soil porosity, increased soil bulk density $(B D)$, aeration and water balance, as well as increases in soil penetration resistance, structural degradation and erosion risk [4-7]. Soil quality can influence yield in terms of quantity and/or quality, which is not negligible when viewed against the background of what is sometimes described as growing "soil degradation" [8].

Alluvial soils have the highest fertility and productivity with respect to other soils [9]. They are present mostly along rivers and are carried by its 
streams during weathering of rocks. Most vegetable production on alluvial soil generally succeeds. The key role in creating alluvial soil has a high groundwater level [10-14]. According to Bednarek and Prusinkiewicz, alluvial river soils constitute about $5 \%$ of Poland's area [15].

There are different ways to assess the physical quality of soils. One of them is soil bulk density $(B D)$, which is often used as an indirect indicator of soil compaction, aeration, strength, and ability to store and transmit water [6, 16-18]. Another parameter of physical soil quality is plant-available water capacity $(P A W)$ [6] that plants can use during the vegetation period. The most important indicator of the chemical and biological quality of soil is organic carbon content $\left(C_{o r g}\right)$. Soil structure is one of the important properties affecting crop production, aeration and water infiltration into the soil profile [19], which may be verified by a structural stability index (StI) [1]. Dexter suggested using an indicator of soil physical quality $(S)$ [4-5]. According to this theory, $S$ is a measure of soil microstructure (especially soil water retention curve), which controls many of the soil physical properties useful for the overall assessment of soil quality. In the literature there are a lot of other indicators of $S P Q$, but that article focuses on the indictors cited above. The objective of this paper is to assess the physical quality of Chernozems Fluvisols of the Odra River in the Racibórz Dolny polder area.

\section{Experimental}

\section{Description of Study Area}

The study area lies on alluvial soils located in the Odra River valley on arable land in Tworków $\left(50^{\circ} 00^{\prime} 16^{\prime \prime} \mathrm{N}, 18^{\circ} 14^{\prime} 09^{\prime \prime} \mathrm{E} ; 190.00 \mathrm{~m}\right.$ a.s.l.), in the south of Poland (the Racibórz District, Silesian Province). Based on the soil map of the 1960s, the original land use was a medium green grassland transformed into arable land. The average annual groundwater level is in the range 1.10-1.50 m below ground level. According to the geographical division by Kondracki [20], the object is situated in the Central European Lowlands province (31), in the macroregion of the Silesian Lowlands (318.5) and in the mesoregion of the Raciborska Basin (318.59).

\section{Soil Description and Soil Sampling}

The field soil tests were carried out in the two agricultural seasons (2012 and 2013) on arable lands. In a field, four soil pits (Nos. 1-4) were made up to a depth of $150 \mathrm{~cm}$. Undisturbed soil samples were taken from each genetic horizon using Kopecky's cylinders (in 3 replications). Also, approximately $1 \mathrm{~kg}$ of disturbed soil from each genetic horizon was used to find the soil texture, and other laboratory analysis were taken.

\section{Meteorological Conditions}

In terms of climate, the study area is considered one of the warmest areas in this region. In the multiannual period 1971-2000, average annual air temperature was $8.5^{\circ} \mathrm{C}$ and total precipitation was $616 \mathrm{~mm}$. In 2012, the average temperature was $9.2^{\circ} \mathrm{C}$ and the sum of atmospheric precipitation was $586 \mathrm{~mm}$, while in 2013 it was $9.0^{\circ} \mathrm{C}$ and $597 \mathrm{~mm}$, respectively (acc. to the Institute of Meteorology and Water Management station in Racibórz). Higher average temperatures have been observed, as has a decrease in rainfall.

\section{Laboratory Analysis}

From soil samples that were collected, the selected physical properties were determined in accordance with the general methodologies stated in Mocek and Drzymała [21]. Soil texture by the Bouyoucose-Casagrande areometric method modified by Prószyński was specified. The content of particle size classes (sand, 2.0-0.05 mm; silt, 0.05-0.002 mm; clay, $<0.002 \mathrm{~mm}$ ) was determined according to the USDA classification [22]. Soil bulk density $(B D)$ by the gravimetric method in Kopecky's cylinders as the mass of dry soil per volume. The weight of this soil core was then determined after drying in an oven at $105^{\circ} \mathrm{C}$ for about $18-24$ hours. The total plant-available water capacity $(P A W)$ was determined as the difference between the moisture retained at $\mathrm{pF}$ 2.5-4.2 using a set for $\mathrm{pF}$ determination with ceramic plates in the 5 and 15 bar pressure plate extractor. Total organic carbon content $\left(C_{\text {org }}\right)$ was calculated by Tiurin's method.

The assessment of soil physical quality $(S P Q)$ was based on the key performance indicators defined by researchers from all around the world. The soil's ability to store and provide water that is available to plant roots was assessed using the plant-available water capacity, $P A W\left(\mathrm{~m}^{3} \cdot \mathrm{m}^{-3}\right)[6,23]$ as:

$$
P A W=\theta_{\mathrm{FC}}-\theta_{\mathrm{PWP}}\left(\mathrm{m}^{3} \cdot \mathrm{m}^{-3}\right)
$$

...where $\theta_{\mathrm{FC}}-$ field water capacity at $\mathrm{pF} 2.5\left(\mathrm{~m}^{3} \cdot \mathrm{m}^{-3}\right)$ and $\theta_{\mathrm{PWP}}$ - the permanent wilting point water content at $\mathrm{pF}$ $4.2\left(\mathrm{~m}^{3} \cdot \mathrm{m}^{-3}\right)$. A $P A W \geq 0.20 \mathrm{~m}^{3} \cdot \mathrm{m}^{-3}$ is often considered "ideal" for maximal root growth and function, while $0.15 \leq P A W<0.20 \mathrm{~m}^{3} \cdot \mathrm{m}^{-3}$ is "good," $0.10 \leq P A W<0.15 \mathrm{~m}^{3} \cdot \mathrm{m}^{-3}$ is "limited," and $P A W<0.10 \mathrm{~m}^{3} \cdot \mathrm{m}^{-3}$ is considered "poor" or "droughty" [6].

Based on $B D$ value, the destruction of soil physical structure, soil compaction and easily field crop production were determined. The $B D$ value should be within the optimal range $0.9-1.2 \mathrm{~g} \cdot \mathrm{cm}^{-3}$ for maximal field crop production, values greater than $1.25-1.30 \mathrm{~g} \cdot \mathrm{cm}^{-3}$ potentially cause yield loss due to inadequate soil aeration, and values below $0.9 \mathrm{~g} \cdot \mathrm{cm}^{-3}$ potentially cause yield loss due to inadequate plant anchoring, reduced $P A W$ capacity, and reduced 
unsaturated flow of water and dissolved nutrients to plant roots $[6,24]$.

The risk for soil structural degradation associated with $C_{\text {org }}$ depletion and improper graining was calculated using a structural stability index (StI) according to Eq. 2 as suggested by Pieri [1] and Reynolds et al. [6]:

$$
S t I=\frac{1.724 \cdot C_{\text {org }}}{(\text { silt }+ \text { clay })} \cdot 100
$$

...where $C_{\text {org }}$ - the soil organic carbon content (\%) and clay + silt - the soil's combined clay and silt content $(\%)$. St $K 5 \%$ indicates a structurally degraded soil; $5 \%<S t I<7 \%$ indicates a high risk of soil structural degradation; $7 \%<S t I<9 \%$ indicates a low risk of soil structural degradation; and $S t I>9 \%$ indicates sufficient $C_{\text {org }}$ to maintain the structural stability. It is conventionally assumed that optimal organic carbon content is $3-5 \%$.

Index of soil physical quality ( $S$ index) was defined by Dexter [4] using van Genuchten parameters [25]. The estimation of these parameters was performed with the Retention Curve programme (RETC) using sand, silt and clay percentages as input. The $S$ index at each layer was calculated as:

$$
S=-n\left(\theta_{\text {sat }}-\theta_{\text {res }}\right)\left[\frac{2 n-1}{n-1}\right]^{\left(\frac{1}{n}-2\right)}
$$

...where $\theta_{\text {sat }}$ and $\theta_{\text {res }}-$ saturated and residual water contents in gravimetric units $\left(\mathrm{kg} \cdot \mathrm{kg}^{-1}\right) ; \mathrm{n}$ - the shape parameter of soil water characteristic (from RETC). The value of $S$ index is always negative, therefore, its absolute value is used. Categories of $S P Q$ index have been as follows: $S \geq 0.050$ indicates "very good" soil physical or structural quality, $0.035 \leq S<0.050$ is "good physical quality," $0.020 \leq S<0.035$ is "poor physical quality" and $S<0.020$ is "very poor" or "degraded" physical quality $[5,26]$.

\section{Statistical Analysis}

The data set consists of analytical results of soil samples collected at the four soil pits. For statistical analysis, the procedures provided by the program Statistica PL version 12.5 were used with a 5\% significance level. For each analyzed physical parameter of soil its minimum and maximum values determined its arithmetic mean, median, standard deviation (SD) and coefficient of variation (CV). Moreover, a Spearman correlation test was conducted for the entire data set. This statistical method was chosen after checking data normality (Shapiro-Wilk test). All data are presented in tables and graphs in order to produce a visual image that is helpful in interpreting the results.

\section{Results and Discussion}

As shown in Table 1, the alluvial river soils are a heterogeneous in terms of texture with a high clay (C) content in top layers, at a depth of 100-150 cm occurs the silty loam (SiL), loam (L) or sandy loam (SL). These results are in agreement with Iqbal et al. [27], Bullinger-Weber et al. [28] and L'uptáčik et al. [29], who had worked in similar soils. In each soil profile, five genetic levels were specified. The high coefficient of variation $(\mathrm{CV})$ value was observed, which is the measure of empirical data deviations from average values. The highest CV was in silt (62.4\%). Sand content in the profiles was between 16 and $76 \%$, silt content between 16 and $62 \%$, and clay content between 8 and $65 \%$ (Table 1, Fig. 1). Other research has documented high variable of sand in alluvial soils $[30,31]$. According to PTG [32], WRB [33] and USDA soil taxonomy [22], examined soils were classified as: Order 7. Chernozemic soils (Polish: Gleby czarnoziemne; WRB: Chernozems, Phaeozems; ST: Mollisols - Aquolls, Udolls), Type 7.4. "Chernoziemic fluvisols" (Polish: Mady czarnoziemne; WRB: Mollic Fluvisol, Endofluvic Phaeozem; ST: Fluvaquentic Endoaquolls).

The $P A W$ and its distribution in the examined soil profiles are shown in Table 2 and Fig. 1. High $P A W$ capacity values $\left(0.2229 \mathrm{~m}^{3} \cdot \mathrm{m}^{-3}\right)$ may be related to the high silt and clay for all soil profiles and also mean $C_{\text {org }}$ content [34]. Touil et al. reported that the hydraulic parameters are mostly sensitive to sand content [35], whereas Gama-Castro et al. [36] found that the high productivity of alluvial soils is largely due to the $P A W$, so this is very important for the observed climate changes [37].

Bulk density $(B D)$ was in the range $0.44 \mathrm{~g} \cdot \mathrm{cm}^{-3}$ (organic compounds) to $1.81 \mathrm{~g} \cdot \mathrm{cm}^{-3}$ (typical mineral soil) and predominantly increasing with depth (Table 1). The $B D$ is one of the most important physical soil properties that characterizes soil compaction and can influence the water properties of soil [38-40]. As illustrated in Fig. 1, a lower mean value of $B D$ was observed in profile No. $1\left(1.09 \mathrm{~g} \cdot \mathrm{cm}^{-3}\right)$, where the sand content was the lowest $(28.2 \%)$, whereas the highest compaction was visible in profile No. $3\left(1.70 \mathrm{~g} \cdot \mathrm{cm}^{-3}\right)$, where the sand content was the highest (45.4\%). The $B D$ range of alluvial soils can be very wide - smaller values were observed in the Ap horizons and increased with depth [36, 41, 42].

The mean value of $C_{\text {org }}$ in soils is low $-1.05 \%$ with the high CV (Table 1, Fig. 1). These results are in agreement with Jones et al., who found that most of the mineral soils in Europe have low or very low organic carbon content $(0-2 \%)$ [43]. Higher $C_{\text {org }}$ contents were observed in the surface layers and lower contents at the bottom of the profile [44]. Ruiz-Sinoga et al. [45] and Gervais-Beaulac et al. [46] noticed that fine fractions, like clay and silt, retain more organic particles than sand fractions. A similar tendency can be observed in the analyzed soils (Fig. 1). 
Table 1. Selected physical characteristics of soils and indicator values of soils physical quality.

\begin{tabular}{|c|c|c|c|c|c|c|c|c|c|c|}
\hline \multirow{2}{*}{$\begin{array}{l}\text { Profile } \\
\text { number }\end{array}$} & \multirow{2}{*}{$\begin{array}{l}\text { Depth } \\
{[\mathrm{cm}]}\end{array}$} & \multirow{2}{*}{ Soil texture group $* / * *$} & \multicolumn{3}{|c|}{$\%$ fraction } & \multirow{2}{*}{$\frac{P A W}{\left(\mathrm{~m}^{3} \cdot \mathrm{m}^{-3}\right)}$} & \multirow{2}{*}{$\frac{B D}{\left(\mathrm{~g} \cdot \mathrm{cm}^{-3}\right)}$} & \multirow{2}{*}{$\begin{array}{l}C_{\text {org }} \\
(\%)\end{array}$} & \multirow{2}{*}{$\begin{array}{l}S t I \\
(\%)\end{array}$} & \multirow{2}{*}{$\frac{S}{(-)}$} \\
\hline & & & Sand & Silt & Clay & & & & & \\
\hline \multirow{5}{*}{1} & $0-30$ & SiCL/gpyi & 18 & 47 & 35 & 0.1599 & 1.44 & 1.92 & 4.0 & 0.020 \\
\hline & $30-46$ & $\mathrm{C} / \mathrm{iz}$ & 31 & 26 & 43 & 0.2114 & 1.12 & 1.26 & 3.1 & 0.021 \\
\hline & $46-63$ & $\mathrm{C} / \mathrm{iz}$ & 16 & 19 & 65 & 0.2805 & 1.06 & 2.09 & 4.3 & 0.035 \\
\hline & $63-94$ & $\mathrm{SCL} / \mathrm{gl}$ & 57 & 29 & 14 & 0.3692 & 0.44 & 3.90 & 15.6 & 0.360 \\
\hline & $94-150$ & $\mathrm{SiL} /$ pyi & 19 & 62 & 19 & 0.2979 & 1.40 & 0.89 & 1,9 & 0.079 \\
\hline \multirow{5}{*}{2} & $0-18$ & $\mathrm{CL} / \mathrm{gi}$ & 25 & 35 & 40 & 0.2293 & 1.32 & 1.71 & 3.9 & 0.021 \\
\hline & $18-34$ & $\mathrm{C} / \mathrm{iz}$ & 18 & 21 & 61 & 0.2283 & 1.29 & 1.22 & 2.6 & 0.017 \\
\hline & $34-52$ & $\mathrm{~L} / \mathrm{gz}$ & 32 & 44 & 24 & 0.1945 & 1.52 & 1.13 & 2.9 & 0.046 \\
\hline & $52-85$ & $\mathrm{SL} / \mathrm{gl}$ & 55 & 33 & 12 & 0.2229 & 1.75 & 0.37 & 1.3 & 0.040 \\
\hline & $85-150$ & $\mathrm{SL} / \mathrm{gl}$ & 76 & 16 & 8 & 0.2433 & 1.61 & 0.53 & 4.0 & 0.054 \\
\hline \multirow{5}{*}{3} & $0-25$ & $\mathrm{~L} / \mathrm{gz}$ & 43 & 35 & 22 & 0.1270 & 1.65 & 0.92 & 2.8 & 0.023 \\
\hline & $25-47$ & $\mathrm{~L} / \mathrm{gz}$ & 45 & 33 & 22 & 0.1482 & 1.81 & 0.52 & 1.6 & 0.012 \\
\hline & $47-75$ & $\mathrm{SL} / \mathrm{gl}$ & 58 & 24 & 18 & 0.1769 & 1.66 & 0.22 & 1.0 & 0.027 \\
\hline & $75-117$ & $\mathrm{~L} / \mathrm{gz}$ & 40 & 43 & 17 & 0.2178 & 1.68 & 0.17 & 0.4 & 0.034 \\
\hline & $117-150$ & $\mathrm{~L} / \mathrm{gz}$ & 41 & 45 & 14 & 0.2531 & 1.68 & 0.14 & 0.3 & 0.050 \\
\hline \multirow{5}{*}{4} & $0-30$ & $\mathrm{CL} / \mathrm{gi}$ & 22 & 40 & 38 & 0.2720 & 1.11 & 2.08 & 4.6 & 0.034 \\
\hline & $30-42$ & SiCL/gpyi & 17 & 55 & 28 & 0.1516 & 1.51 & 0.98 & 2.1 & 0.022 \\
\hline & $42-71$ & $\mathrm{SiL} /$ pyi & 27 & 53 & 20 & 0.2352 & 1.56 & 0.33 & 0.8 & 0.043 \\
\hline & $71-100$ & $\mathrm{SL} / \mathrm{gl}$ & 54 & 33 & 13 & 0.1953 & 1.65 & 0.21 & 0.8 & 0.041 \\
\hline & $100-150$ & $\mathrm{SL} / \mathrm{gl}$ & 67 & 25 & 8 & 0.2445 & 1.62 & 0.40 & 2.1 & 0.051 \\
\hline \multicolumn{11}{|c|}{ Basic descriptive statistics } \\
\hline \multirow{6}{*}{\multicolumn{2}{|c|}{ Index value: }} & Minimum & 16.0 & 16.0 & 8.0 & 0.1270 & 0.44 & 0.14 & 0.3 & 0.012 \\
\hline & & Maximum & 76.0 & 62.0 & 65.0 & 0.3692 & 1.81 & 3.90 & 15.6 & 0.360 \\
\hline & & Mean & 38.0 & 35.9 & 26.1 & 0.2229 & 1.44 & 1.05 & 3.0 & 0.052 \\
\hline & & Median & 36.0 & 34.0 & 21.0 & 0.2256 & 1.54 & 0.91 & 2.4 & 0.035 \\
\hline & & $\mathrm{SD}$ & 18.4 & 12.6 & 16.3 & 0.06 & 0.32 & 0.93 & 3.3 & 0.074 \\
\hline & & CV $(\%)$ & 48.2 & 35.1 & 62.4 & 25.72 & 22.27 & 88.9 & 108.4 & 144.4 \\
\hline
\end{tabular}

* acc. to USDA; ** acc. to PTG

As shown in Table 1 and Fig. 1, the mean value of StI indicates a very high risk of soil degradation (3.0\%). Undoubtedly, many factors have impacted this indicator, such as sand, silt and clay contents and $C_{\text {org }}$ content [6, 47, 48].

The mean value of $S$ index (0.052) indicates "very good" soil physical quality (Table 1). The values of $S$ index suggest that five of the 20 soil layers had very good physical quality $(S P Q)$, five of them had good $S P Q$, eight layers had poor $S P Q$ and only two layers of all had very poor $S P Q$ (Table 1). Very good results of the $\mathrm{S}$ index were recorded in the layers of the lower soil profiles (0.059), while the lowest values of the $S$ index were recorded in top layers of soil (0.018-0.025). Pulido-Moncada et al. [49] reported that the $S$ index can provide inconsistent designations of $S P Q$ and has a lack of consistency with other physical indicators for some soils. Jong Van Lier [50] argues that bulk density or total porosity are much more easily determined than the water retention curve for obtaining $S$ index, which disqualifies $S$ index as an advantageous indicator of relative soil physical quality.

Profile No. 1 saw the best relationship between percentages of sand, silt and clay content (Table 1, Fig. 1). The high content of $P A W\left(0.2638 \mathrm{~m}^{3} \cdot \mathrm{m}^{-3}\right)$ 
and $C_{\text {org }}$ content $(1.05 \%)$, and small value of $B D$ $\left(1.09 \mathrm{~g} \cdot \mathrm{cm}^{-3}\right)$ were observed here, which is a positive feature of soil. The mean values of StI and $\mathrm{S}$ indexes for this soil profile are the best - at $5.78 \%$ and 0.103 , respectively. The high proportion of sand (45\%) and the smallest content of clay (18\%) was observed in profile
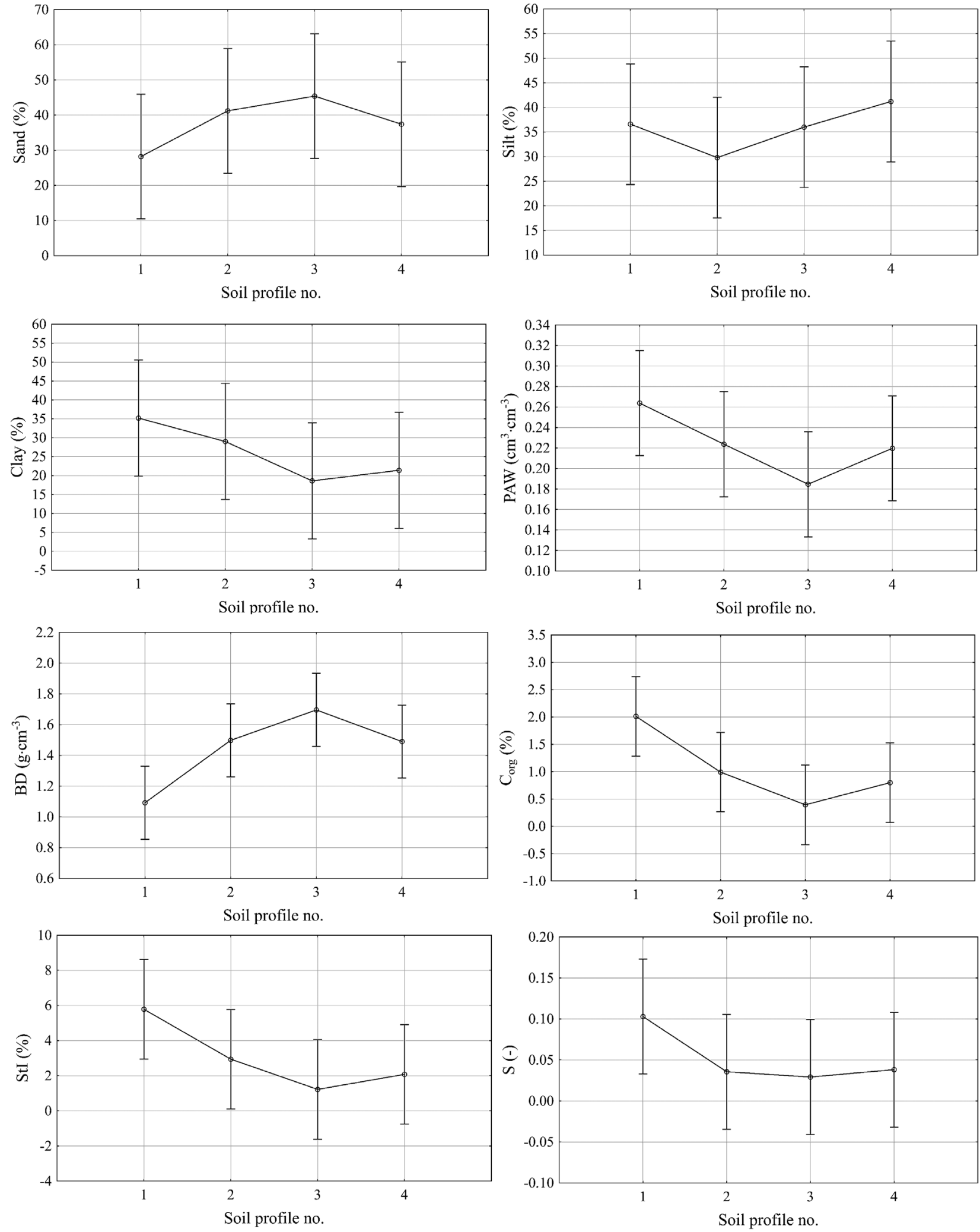

Fig. 1. Comparison of selected physical characteristics and soil quality indices with $95 \%$ confidence interval 
Table 2. Correlation matrix (Spearman Rho) for the entire data set.

\begin{tabular}{|c|c|c|c|c|c|c|c|c|}
\hline Variables: & Sand & Silt & Clay & $P A W$ & $B D$ & $C_{o r g}$ & $S t I$ & $S$ \\
\hline Sand & 1.00 & -0.43 & $-0.83^{*}$ & -0.03 & $0.55^{*}$ & $-0.49 *$ & -0.23 & 0.42 \\
\hline Silt & -0.43 & 1.00 & 0.07 & -0.13 & 0.09 & -0.14 & -0.30 & 0.04 \\
\hline Clay & $-0.83 *$ & 0.07 & 1.00 & -0.15 & $-0.60 *$ & $0.66 *$ & 0.44 & $-0.67 *$ \\
\hline$P A W$ & -0.03 & -0.13 & -0.15 & 1.00 & $-0.48 *$ & 0.21 & 0.25 & $0.66 *$ \\
\hline$B D$ & $0.55^{*}$ & 0.09 & $-0.60 *$ & $-0.48^{*}$ & 1.00 & $-0.87^{*}$ & $-0.78 *$ & -0.02 \\
\hline$C_{\text {org }}$ & $-0.49 *$ & -0.14 & $0.66 *$ & 0.21 & $-0.87 *$ & 1.00 & $0.93 *$ & -0.20 \\
\hline StI & -0.23 & -0.30 & 0.44 & 0.25 & $-0.78 *$ & $0.93 *$ & 1.00 & -0.04 \\
\hline$S$ & 0.42 & 0.04 & $-0.67 *$ & $0.66^{*}$ & -0.02 & -0.20 & -0.04 & 1.00 \\
\hline
\end{tabular}

* Coefficients significant at $\mathrm{P}<0.05$

Spearman correlation coefficient between the granulometric composition and selected indicator values of soil physical quality are presented in Table 2. The $B D$ negatively influenced the $P A W$ values $(\mathrm{r}=-0.48)$. A similar correlation was found by Asgarzadeh et al. [51]. The $P A W$ and $B D$ appear most promising as indicators for routine evaluation and monitoring of soil physical quality $[52,53]$. Spearman correlation between $C_{\text {org }}$ concentration and sand content was significantly negative and average $(\mathrm{r}=-0.49)$, but with $B D$ was significantly negative and high $(\mathrm{r}=-0.87)$. There was also a strong and significant correlation between $C_{\text {org }}$ concentration and clay content $(\mathrm{r}=0.66)$, and very strong with $S t I$ $(\mathrm{r}=0.93)$. Index of soil physical quality $(S$ index) was strongly negatively correlated with concentration of clay content in the soil $(\mathrm{r}=-0.67)$, and strongly positively correlated with $P A W$ content $(\mathrm{r}=0.66)$ (Table 2). Similar results were observed by Asgarzadeh et al. [51], Vizitiu et al. [54], Paluszek [3] and Souza et al. [55].

\section{Conclusions}

The results of the research indicate that soil texture, $P A W, B D, C_{\text {org }}$, StI and $S$ index can be used to analyze and evaluate alluvial soil physical quality. There are two visible characteristics of soil quality. The $B D$, a typical physical parameter of soil, was strongly correlated with StI, sand and clay contents, whereas $P A W$ - a typical water parameter of soil, was strongly correlated with $S$ index. The use of $S$ index as an indicator, which is based on simulation values from RETC, is less viable because other indicators such as $B D, C_{\text {org }}$, porosity, granulometric compositions and visual examination are much more easily determined and more consistent than $S$ index. In conclusion, the transformation of grassland into arable land was rather a negative effect of soil physical quality had destructive consequences on $B D, C_{\text {org }}$, content and StI than expected [56]. We should bear in mind that grasslands have some potential to sequester atmospheric $\mathrm{CO}_{2}$ as stable carbon $(\mathrm{C})$ in the soil and hence could contribute to mitigation of climate change [57] and also play a key soil-protecting role against erosion [58]. The negative impacts on the soil environment caused by changes in agricultural practices linked to cultivation can cause crop loss in wet years. The studied geographical area is characterized by medium-heavy soils of the types most suitable for growing permanent pasture. The soils of this type play an important role in soil-water retention [59] and environmental development, and therefore should be protected.

\section{Acknowledgements}

This Research was financed by the Ministry of Science and Higher Education of the Republic of Poland. The work was carried out under statutory activities of the Department of Land Reclamation and Environmental Development. I would like to thank the authorities of the Agro-Industrial Company AGROMAX in Racibórz for providing an area for field study.

\section{Conflict of Interest}

The authors declare no conflict of interest.

\section{References}

1. PIERI C.J.M.G. Fertility of Soils: A Future for Farming in the West African Savannah. Springer-Verlag. Berlin, Germany, 1992.

2. KARLEN D.L., MAUSBACH M.J., DORAN J.W., CLINE R.G., HARRIS R.F., SCHUMAN G.E. Soil Quality: A Concept, Definition, and Framework for Evaluation (A Guest Editorial). Soil Sci. Soc. Am. J. 61, 4, 1997.

3. PALUSZEK J. Criteria of Evaluation of Physical Quality of Polish Arable Soils. Acta Agrophysica, Rozprawy i Monografie. 191, 2011 [In Polish].

4. DEXTER A.R. Soil physical quality. Part I: theory, effects of soil texture, density and organic matter and effects on root growth. Geoderma. 120, 201, 2004a. 
5. DEXTER A.R. Soil physical quality: Part II. Friability, tillage, tilth and hard-setting. Geoderma. 120, 215, 2004b.

6. REYNOLDS W.D., DRURY C.F., TAN C.S., FOX C.A., YANG X.M. Use of indicators and pore volume-function characteristics to quantify soil physical quality. Geoderma. 152, 252, 2009.

7. CHERUBIN M.R.,. KARLEN D.L., FRANCO A.L.C., TORMENA C.A., CERRI C.E.P., DAVIES C.A., CERRI C.C. Soil physical quality response to sugarcane expansion in Brazil. Geoderma. 267, 156, 2016.

8. JIE CH., JING-ZHANG CH., MAN-ZHI T., ZI-TONG G. Soil degradation: a global problem endangering sustainable development. Journal of Geographical Sciences. 12, 243, 2002.

9. HUONG P.T.T., EVERAARTS A.P., NEETESON J.J., STRUIK P.C. Vegetable production in the Red River Delta of Vietnam. I. Opportunities and constraints. NJAS Wageningen Journal of Life Sciences. 67, $27,2013$.

10. DOBROVOL'SKI G.V., BALABKO P.N., STASJUK N.V., BYKOVA E.P. Alluvial soils of river floodplains and deltas and their zonal differences. Arid Ecosystems. 1, 119, 2011.

11. PIRASTRU M., NIEDDA M. Evaluation of the soil water balance in an alluvial flood plain with a shallow groundwater table. Hydrol. Sci. J. 58, 898, 2013.

12. LIU H., LI B., REN T. Soil profile characteristics of highproductivity alluvial cambisols in the North China Plain. J. Integr. Agric. 14, 765, 2015.

13. DWEVEDI A., KUMAR P., KUMAR P., KUMAR Y., SHARMA Y.S., KAYASTHA A.M. Soil sensors: detailed insight into research updates, significance, and future prospects. Chapter in New Pesticides and Soil Sensors. Academic Press. 561, 2017.

14. YASSOGLOU N., TSADILAS CH., KOSMAS C. Specific Characteristics of Alluvial Soils. In: The Soils of Greece. World Soils Book Series, Springer, Cham. 2017.

15. BEDNAREK R., PRUSINKIEWICZ Z. Soil geography. PWN, Warszawa, pp. 228, 1999 [In Polish].

16. HAKL J., ŠANTRU゚Č EK J., KOCOURKOVÁ D., FUKSA P. The effect of the soil compaction on the contents of alfalfa root reserve nutrients in relation to the stand density and the amount of root biomass. Soil Water Res. 2 (2), 54, 2007.

17. NAWAZ M.F., BOURRIÉ G., TROLARD F. Soil compaction impact and modelling. A review. Agron. Sustainable Dev. 33, 291, 2013.

18. REYNOLDS W.D., DRURY C.F., YANG X.M., TAN C.S. Optimal soil physical quality inferred through structural regression and parameter interactions. Geoderma. 146, 466, 2008.

19. MURŠEC M., LEVEQUE J., CHAUSSOD R., CURMI P. The impact of drip irrigation on soil quality in sloping orchards developed on marl - a case study. Plant, Soil Environ. 64, 20, 2018.

20. KONDRACKI J. Regional geography of Poland. PWN. Warszawa, 2011 [In Polish].

21. MOCEK A., DRZYMAŁA S. Genesis, analysis and classification of soils. Wyd. UP Poznań, 2010 [In Polish].

22. SOIL SURVEY STAFF. Soil Taxonomy: A Basic System of Soil Classification for Making and Interpreting Soil Surveys. $2^{\text {nd }}$ Ed. Natural Resources Conservation Service. U.S. Department of Agriculture Handbook, 1999.

23. WHITE R.E. Principles and Practice of Soil Science. $4^{\text {th }}$ Ed. Oxford, UK, Blackwell Publishing, 2006.

24. DREWRY J.J., CAMERON K.C., BUCHAN G.D. Pasture yield and soil physical property responses to soil compaction from treading and grazing: a review. Aust. J. Soil Res. 46, 237, 2008.

25. VAN GENUCHTEN M.TH. A closed-form equation for predicting the hydraulic conductivity of unsaturated soils. Soil Sci. Soc. Am. J. 44, 892, 1980.

26. DEXTER A.R., CZYZ E.A. Applications of S-theory in the study of soil physical degradation and its consequences. Land Degradation \& Development. 18, 369, 2007.

27. IQBAL J., THOMASSON J.A., JENKINS J.N., OWENS P.R., WHISLER F.D. Spatial Variability Analysis of Soil Physical Properties of Alluvial Soils. Soil Science Society of America Journal Abstract - Soil \& Water Management \& Conservation. 69, 1338, 2005.

28. BULLINGER-WEBER G., LE BAYON R., GUENAT C., GOBAT J-M. Influence of some physicochemical and biological parameters on soil structure formation in alluvial soils. Eur. J. Soil Biol. 43, 57, 2007.

29. L'UPTÁČIK, P., MIKLISOVÁ, D., KOVÁČ, L. Diversity and community structure of soil Oribatida (Acari) in an arable field with alluvial soils. Eur. J. Soil Biol. 50, 97, 2012.

30. SAĞLAM M., ÖZTÜRK H.S., ERŞAHIN S., ÖZKAN A.İ. Spatial variation of soil physical properties in adjacent alluvial and colluvial soils under Ustic moisture regime. Hydrol. Earth Syst. Sci. Discuss. 8, 2011.

31. REZA S.K., NAYAK D.C., CHATTOPADHYAY T., MUKHOPADHYAY S., SINGH S.K., SRINIVASAN R.. Spatial distribution of soil physical properties of alluvial soils: a geostatistical approach. Archives of Agronomy and Soil Science. 2015.

32. PTG. Polish soil classification. $5^{\text {th }}$ Ed. Soil Science Annual. 62 (3), 2011 [In Polish].

33. IUSS Working Group WRB. World Reference Base for Soil Resources 2014. International soil classification system for naming soils and creating legends for soil maps. Rome: FAO, 2014, seria: World Soil Resources Reports No. 106. ISBN 978-92-5-108369-7.

34. RAWLS W.J., PACHEPSKY Y.A., RITCHIE J.C., SOBECKI T.M., BLOODWORTH H. Effect of soil organic carbon on soil water retention. Geoderma. 116, 61, 2003.

35. TOUIL S., DEGRÉ A., CHABACA M.N. Sensitivity analysis of point and parametric pedotransfer functions for estimating water retention of soils in Algeria. Soil. 2, 647, 2016.

36. GAMA-CASTRO J.E., SOLLEIRO-REBOLLEDO E., VALLEJO-GÓMEZ E. Weathered pumice influence on selected alluvial soil properties in west Nayarit. Mexico. Soil Tillage Res. 55, 143, 2000.

37. TÁRNÍK A., LEITMANOVÁ M. Analysis of the Development of Available Soil Water Storage in the Nitra River Catchment. IOP Conf. Series: Materials Science and Engineering. 245, 2017.

38. CASANOVA M., TAPIA E., SEGUEL O., SALAZAR O. Direct measurement and prediction of bulk density on alluvial soils of central Chile. Chilean Journal of Agricultural Research. 76, 105, 2016.

39. HAMZA M.A., ANDERSON W.K. Soil compaction in cropping systems. A review of nature, causes and possible solutions. Soil Tillage Res., 82, 121, 2005.

40. GŁĄB T. Effect of soil compaction on root system morphology and productivity of Alfalfa (Medicago sativa L.). Polish J. of Environ Stud. 20 (6), 1473, 2011.

41. UMWENI A.S., OGUNKUNLE A.O. Irrigation Capability Evaluation of Illushi Floodplain, Edo State, Nigeria. International Soil and Water Conservation Research. 2, 2, 2014. 
42. MELCHIORRE M., DI GIUSEPPE D., TESSARI U., FACCINI B. Particle density distribution in a fluvial floodplain. Rend. Online Soc. Geol. It. 39, 2, 2016.

43. JONES A., PANAGOS P., BARCELO S., BOURAOUI F., BOSCO C., DEWITTE O, GARDI C., ERHARD M., HERVÁS J., HIEDERER R., JEFFERY S., LÜKEWILLE A., MARNO L., MONTANARELLA L., OLAZÁBAL C, PETERSEN J. E., PENIZEK V., STRASSBURGER T., TÓTH G., VAN DEN EECKHAUT M., VAN LIEDEKERKE M.,VERHEIJEN F., VIESTOVA E., YIGINI Y. The state of soil in Europe, JRC reference report. Joint Research Centre of the European Commission, Ispra, 2012.

44. SAINT-LAURENT D., PARADIS R., DROUIN A., GERVAIS-BEAULAC V. Impacts of Floods on Organic Carbon Concentrations in Alluvial Soils along Hydrological Gradients Using a Digital Elevation Model (DEM). Water. 8, 5, 2016.

45. RUIZ-SINOGA J.D, PARIENTE S., DIAZ A.R., MARTINEZ MURILLO J.F. Variability of relationships between soil organic carbon and some soil properties in Mediterranean rangelands under different climatic conditions (South of Spain). Catena. 94, 17, 2012.

46. GERVAIS-BEAULAC V., SAINT-LAURENT D., BERTHELOT J.S., MESFIOUI M. Organic carbon distribution in alluvial soils according to different flood risk zones. Journal of Soil Science and Environmental Management. 4, 8, 2013.

47. MONCADA M.P., GABRIELS D., CORNRLIS W., LOBO D. Comparing Aggregate Stability Tests for Soil Physical Quality Indicators. Land Degradation \& Development. 26, 843, 2013.

48. BESALATPOUR A.A., AYOUBI S., HAJABBASI M.A., MOSADDEGHI M.R., SCHULIN R. Estimating wet soil aggregate stability from easily available properties in a highly mountainous watershed. Catena. 111, 72, 2013.

49. MONCADA M.P., BALL B.C., GABRIELS D., LOBO D., CORNELIS W.M. Evaluation of Soil Physical Quality Index $\mathrm{S}$ for Some Tropical and Temperate MediumTextured Soils. Soil Sci. Soc. Am. J., 79, 9, 2015.

50. JONG VAN LIER QUIRIJN DE. Revisiting the S-index for soil physical quality and its use in Brazil. Revista Brasileira de Ciência do Solo, 38 (1), 1, 2014.
51. ASGARZADEH H., MOSADDEGHI M.R., MAHBOUBI A.A., NOSRATI A., DEXTER A.R. Soil water availability for plants as quantified by convention available water, least limiting water range and integral water capacity. Plant Soil. 335, 229, 2010.

52. MOEBIUS B.N., VAN ES H.M., SCHINDELBECK R.R., IDOWU O.J., CLUNE D.J., THIES J.E. Evaluation of laboratory-measured soil properties as indicators of soil physical quality. Soil Science. 172, 895, 2007.

53. MONCADA M.P., PENNING L.H., TIMM L.C., GABRIELS D., CORNELIS W.M. Visual examinations and soil physical and hydraulic properties for assessing soil structural quality of soils with contrasting textures and land uses. Soil \& Tillage Research. 140, 20, 2014.

54. VIZITIU O., CALCIU I., PĂNOIU I., SIMOTA C. Soil Physical Quality as Quantified By S Index and Hidrophysical Indices of Some Soils from Argeş Hydrographic Basin. Research Journal of Agricultural Science. 43, 249, 2011.

55. SOUZA R., SOUZA E., MACIEL NETTO A., QUINTÃO DE ALMEIDA A., BARROS JÚNIOR G., RALIUSON INÁCIO SILVA J., ROMUALDO DE SOUSA LIMA J., CELSO DANTAS ANTONINO A. Assessment of the physical quality of a Fluvisol in the Brazilian semiarid region. Geoderma Regional. 10, 175, 2017.

56. VIRTO I., IMAZ M.J., FERNÁNDEZ-UGALDE O., GARTZIA-BENGOETXEA N., ENRIQUE A., BESCANSA P. Soil degradation and soil quality in Western Europe: Current situation and future perspectives. Sustainability. 7, 313, 2015.

57. ABDALLA M., HASTINGS A., SMITH P., CHADWICK D.R., JONES D.L., EVANS C.D., JONES M.B., REES R.M. Critical review of the impacts of grazing intensity on soil organic carbon storage and other soil quality indicators in extensively managed grasslands. Agriculture, Ecosystems \& Environment. 253, 62, 2018.

58. KRASOWICZ S., OLESZEK W., HORABIK J., DĘBICKI R., JANKOWIAK J., STUCZYŃSKI T., JADCZYSZYN J. Rational management of the soil environment in Poland. polish Journal of Agronomy. 7, 43, 2011 [In Polish].

59. BOREK Ł., BOGDAŁ A. Soil water retention of the Odra River alluvial soils (Poland): Estimating parameters by RETC model and laboratory measurements. Applied Ecology And Environmental Research. 16 (4), 4681, 2018. 